
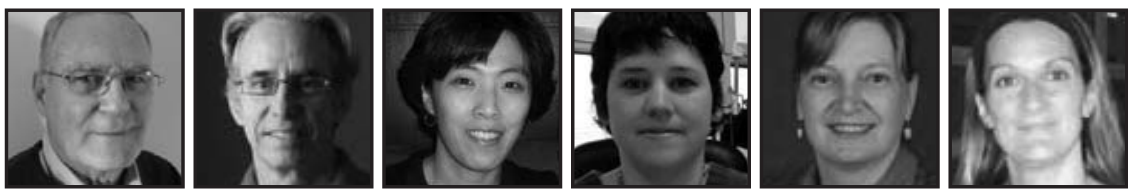

\title{
Teacher-Based Inquiry in the BCT Project
}

\author{
A.E.Ted Wall, Alain Breuleux, Gyeong Mi Heo, Karen Rye, \\ Marie-Helen Goyetche \& Véronique Lemay
}

\section{ABSTRACT}

Over the past four years, teacher-based inquiry has played a central role in the Building Community Through Telecollaboration Project, which involves Quebec elementary school teachers in a community of practice focused on the integration of ICT-supported learning into the classroom. During the school year, the teachers met in four face-to-face meetings. Between these meetings, three Cycle Team Leaders facilitated ongoing collaboration using a variety of communication tools. Some of the questions that were addressed in the project and the results that were generated through its multi-organizational partnership are shared along with some of the major lessons learned.

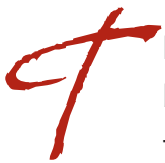

he major purpose of this paper is to illustrate the crucial role that inquirybased activities have had on the development of a community of practice among elementary school teachers in Quebec's English-speaking school boards (Wenger, 1998; Wenger, McDermott, \& Snyder, 2002). The participants in this community of practice include teachers, school administrators, consultants and university personnel. Several features of this community of practice are in line with recent recommendations on effective professional learning, namely, its focus on ICT-supported learning in the classroom, its emphasis on teachers meeting and learning from each other over an extended period of time, the use of group processes to support collegial sharing, as well as the use of teacher inquiry and knowledge building processes (Darling-Hammond, Wei, Andree, Richardson, \& Orphanos, 2009; Easton, 2008; Killion \& Roy, 2009). In addressing the role of teacher inquiry within our community of practice, we will share some of the key questions we have asked and consider 
some of the knowledge that has been generated. We will highlight some of the processes that have been used, the benefits and challenges of using them and the interesting and important results that have emerged from this multi-organizational partnership.

\section{What is the Building Community through Telecollaboration (BCT) Project?}

The Building Community through Telecollaboration Project (BCT Project) stemmed from a CEFRIO Research Report entitled IT-Supported Learning and Networking in the Anglophone Educational Community of Québec (Wall, Breuleux, \& Tanguay, 2006) that identified key factors that influence the use of information and communication technologies (ICT) in support of student learning. In addition to having up-to-date computers, access to the Internet and suitable technical support, the study found that teachers had to acquire a variety of new pedagogical and technical skills if ICT-supported learning was to become more widespread. At the same time, it was found that relevant professional learning opportunities had to be provided and educational leaders had to organize in-school time and support for the teachers to acquire the required expertise. Many of these findings echoed ones emerging from the ground-breaking École Éloingnée en Réseau Project (EER Project: http:// www.eer.qc.ca/) that provided Internet-enabled collaborative learning possibilities in francophone schools in Quebec, mostly in remote areas. The BCT Project plan, while inspired to a large extent by the success of the EER Project, took into consideration the ecology of the English-speaking school community to achieve similar goals. Moreover, the ongoing research from the EER Project influenced the responses to the teacher-based inquiry questions that arose throughout the BCT Project (Laferrière et al., 2006).

In June 2006, LEARN Quebec hosted a Community Consensus Meeting where stakeholders from across Quebec reviewed the above report. After a series of daylong discussions, the participants underscored the importance of ensuring that the following guidelines were adhered to when implementing the report's recommendations. First and foremost, those attending the session stressed that the Quebec Education Program must provide the guiding vision and ICT should be viewed as simply providing the tools to support it. Second, when making decisions about teaching and learning, pedagogy must come first and technology must be at its service. Third, it was recognized that additional research was needed on the impact of ICT-supported 
learning as well as on the means to facilitate the increased use of ICT strategies in the classroom. Finally, those in attendance underscored the value and importance of developing a supportive learning community to facilitate the development and sharing of professional knowledge.

Following the above Community Consensus Meeting, representatives from LEARN Quebec and CEFRIO met with colleagues from MELS and the DirectorsGeneral of English-speaking Quebec School Boards to discuss the potential of creating a professional development project designed to address the recommendations in the CEFRIO Report. The proposed name of the project, Building Community through Telecollaboration (BCT), reflected its major purpose of bringing together educators who were interested in ICT-supported learning in English-speaking communities across Quebec, with a special emphasis on meeting the needs of small, remote, rural communities. After gaining the support of the Directors-General and MELS, colleagues at CEFRIO and LEARN Quebec created a BCT Lead Team that consisted of two experienced ICT animators from LEARN Quebec, a doctoral student, as well as two professors from McGill University, one of whom was retired.

The BCT Lead Team met on a number of occasions and with the input of colleagues from CEFRIO and Learn Quebec further shaped the purpose of the project and its basic operational features. Since its inception, the basic purpose of the BCT Project has been to encourage, facilitate and support collaboration among students, teachers and educational leaders to enhance learning across the community. Each year, the participants in the BCT Project have confirmed its appropriateness and relevance. Over the past four years, the major objectives of the project have been slightly modified to meet emerging needs; as Figure 1 illustrates, the objectives for the current year (2010-2011) are to:

- facilitate the integration of ICT into teaching practices to enhance student learning;

- encourage collaboration among students and teachers to facilitate learning;

- encourage teachers to reflect on their practices and share expertise with others; and

- facilitate the development of a community of practice network across Quebec.

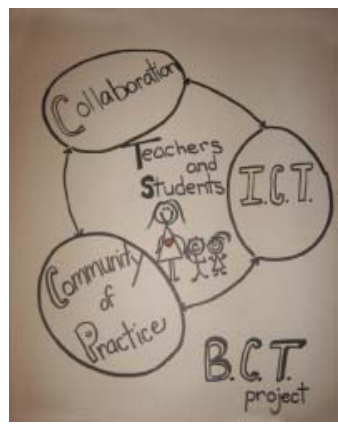

Fig. 1: Key elements in the $\mathrm{BCT}$ project 
In order to reach the above objectives, participants in the BCT Project meet on four separate occasions throughout the school year and use a variety of online tools to communicate and collaborate in between those sessions. In addition, online support is available and at times in-person support is provided by members of the BCT Lead Team. Strategic advice regarding the evolution of the project is provided by the BCT Coordinating Committee that consists of members of the BCT Lead Team and representatives from CEFRIO, LEARN Quebec and the Quebec Ministry of Education, Recreation and Sports.

\section{How has the BCT Project evolved over the past four years?}

Before discussing the inquiry-based activities that are central to the objectives of the BCT Project, it may be helpful to provide more information on its evolution. The project is currently in its fourth year (2010-2011), during the first two years, the BCT Lead Team worked with approximately 30 teachers and their educational administrators in sixteen elementary schools across Quebec. The teachers and administrators were invited to meet four times each year in Face-to-Face (F2F) meetings in September, November, February and April or May. During those sessions, the purpose and objectives of the project were discussed and information on the use of ICT-supported classroom learning activities, based on the Quebec Education Program, was presented along with information on how to develop collaborative student learning projects. In addition, a variety of ICT tools were introduced and used during those F2F sessions by the teachers including email, blogs, wikis, Google docs and Voice Thread. The teachers were also introduced to the use of Live Classroom, a synchronous online collaboration tool supported by LEARN Quebec, that allows teachers and educational leaders to meet with members of the BCT Lead Team or on their own at pre-arranged times. The Live Classroom platform facilitated the presentation of PowerPoint presentations as well as online discussions by the entire group or smaller groups as was deemed necessary (Breuleux, Heo, Wall, Morgan, \& Flores, 2009).

During the first two years, the teachers were encouraged to use previously designed projects that were available on the Internet or develop their own collaborative student projects. A fundamental guideline that was employed during those first two years was to encourage teachers to learn at their own pace. In fact, the teacher feedback emphasized the importance of "taking baby steps" and the value of "reaching out for support" from BCT colleagues. 
At the end of the second year, several important organizational changes were made in the project. One of them was the establishment of three networks based on the three Cycles that are used in Quebec elementary schools. In addition, three teachers who were teaching in the different cycles joined the BCT Lead Team. They were offered one-day of release time each week to provide ongoing leadership and support for the teachers in their Cycle Team. The three Cycle Leaders meet on a weekly basis with their university-based colleagues, to review the progress that is being made, share feedback and suggestions from the teachers in their cycles, and plan, deliver and evaluate the professional learning activities that take place in the F2F and online sessions of the project (Heo, Anderson, Goyetche, Taker, \& Breuleux, 2011).

In addition to the establishment of a more distributed leadership system, LEARN Quebec opened the Sakai Learning Community Portal (http://sakai.learnquebec.ca). The online space allows the teachers in each cycle to engage in open and sustainable interaction by sharing experiences, thoughts, knowledge, and resources, which can foster inquiry processes in relation to their professional practice, and hence to create a shared repertoire developed within the BCT community of practice (Garrison, 2007; Moore \& Barab, 2002; Palincsar, Magnusson, Marano, Ford, \& Brown, 1998; Schlager \& Fusco, 2003).

\section{What role does inquiry play in the BCT Project?}

With regards to the many forms of inquiry in education, see for example the excellent overview by Aulls \& Shore (2008), the BCT project engages participants in the following: reflective practice, collaborative action research, and collective problem solving. These three forms of inquiry are encapsulated in the design-based research approach (Bereiter, 2005; Brown, 1992; Collins, Joseph, \& Bielaczyc, 2004; Schoenfeld, 2006) that has been a central feature of the project since its inception. The design research process is focused on what works, what needs to be improved and a commitment to gaining a deeper understanding of the benefits, challenges and success factors that underlie the activities that are under investigation. In the case of the BCT Project, those activities include student learning, teacher learning and the leadership efforts of educational administrators who support the project, with a special emphasis on collaboration. 
Thus, a major focus of the project is on questions related to what actually happens in the classroom as well as online related to student and teacher collaborative learning. Central to the above process is the ongoing collaboration among the teachers and the members of the BCT Lead Team. Hence, questions are routinely posed related to the development, implementation and evaluation of student learning and the professional learning associated with it. Moreover, there has been a continued emphasis on the importance of posing questions that encourage reflection on the part of all BCT participants and the generation of knowledge that can be shared related to the answers to those questions. Thus, a host of inquiry-based questions have been posed to and by teachers, educational leaders and members of the BCT Lead Team in F2F meetings, as well as online.

\section{How are the professional learning needs of the BCT teachers met?}

Given the central role of ongoing professional learning in the project, some of the first inquiry-based questions were related to the pedagogical and technological skill level of the teachers. Initially, survey questions were posed to gather this information; however, we began to realize that we needed to develop a more appropriate framework for considering the differential learning needs of the teachers. At the same time, we wanted to create a learning continuum that encouraged the teachers to reflect on their own progress in relation to the expertise they wished to acquire. Table 1 presents the results related to the assessment of computer proficiency during the third year of the project. As the average percentage at each level shows, there was a wide range of computer expertise.

The results related to the self-assessment of the teachers in relation to the classroom use of information technology are presented in Table 2. Again, these results show the widespread professional learning needs that are evident in the group. In fact, one of the major challenges of the BCT Project has been to design F2F and online learning sessions to effectively and efficiently meet these needs. 
Table 1:

Self-Assessment of Computer Proficiency by BCT Teachers

\begin{tabular}{l|l|l|r} 
& LEVELS & DESCRIPTIONS & $\%$ \\
\hline 2 & Unfamiliar & Minimal experience with computer technologies & $0 \%$ \\
\hline 3 & Beginner & $\begin{array}{l}\text { Able to perform basic functions in Word and e-mail } \\
\text { applications }\end{array}$ & $\begin{array}{l}\text { Beginning to use computer technologies, but regularly } \\
\text { need considerable support }\end{array}$ \\
\hline 4 & Average & Quite competent in the above and PowerPoint applications & $41.4 \%$ \\
\hline 5 & Advanced & $\begin{array}{l}\text { Competently use a broad spectrum of software including } \\
\text { digital camera, scanner, and social networking applications }\end{array}$ & $31.0 \%$ \\
\hline 6 & Expert & $\begin{array}{l}\text { Very proficient in using a wide variety of computer } \\
\text { technologies }\end{array}$ & $10.3 \%$
\end{tabular}

Table 2:

Self-Assessment of Classroom Use of Information Technology

\begin{tabular}{l|l|l|r} 
& LEVELS & DESCRIPTIONS & $\%$ \\
\hline 2 & Awareness & $\begin{array}{l}\text { I am aware that technology exists, but I am nervous about } \\
\text { using it in the classroom }\end{array}$ & $0 \%$ \\
\hline 3 & Acquiring & $\begin{array}{l}\text { I can comfortably use technology for certain tasks and } \\
\text { appreciate that it can be helpful in the teaching-learning } \\
\text { process in my classroom }\end{array}$ & $34.5 \%$ \\
\hline 4 & Adapting & $\begin{array}{l}\text { I view technology as a set of tools to facilitate learning in } \\
\text { my classroom. I can use different computer applications } \\
\text { and peripherals with my students }\end{array}$ & $37.9 \%$ \\
\hline 5 & Mastery & $\begin{array}{l}\text { I can creatively apply computer technologies to support } \\
\text { teaching and learning in my class }\end{array}$ & $17.2 \%$ \\
\hline
\end{tabular}


The above quantitative data answered several important inquiry-based questions; however, some of the most relevant information emerged from the group discussions and focus group feedback that the teachers shared about the challenges of acquiring increased competence related to ICT-supported learning. On many occasions, experienced BCT teachers shared their initial concerns and fears related to the steep learning curve they initially faced. Due to the collegial sharing of these fears, a basic mantra circulated throughout our community of practice, namely, "remember to take baby steps."

Some of the most important lessons we have learned are related to the factors that impact on the professional learning of the teachers. As we and others have found (Bubb \& Earley, 2009; Glazer \& Hannafin, 2006), teachers are extremely busy and it is difficult for them to find the time to actually practice the technological skills that they need and at the same time acquire the pedagogical know-how that allows them to feel competent and confident when they are using ICT tools to support learning in their classrooms. Most importantly, we have found that a sure way to discourage teachers from continuing in our community of practice is to set unrealistic deadlines and press them to try and meet them. In our F2F sessions, these "lessons learned" were routinely passed on by the Cycle Leaders as well as by the other more experienced teachers in the groups.

As the BCT Project evolved, it was necessary to adapt the way we gathered information on the key questions that were posed. For example, Table 3 shows the results of a set of questions that were used, during the first F2F meeting in the start of the fourth year (2010-2011) of the project, to encourage self-assessment and reflection by the teachers regarding their progress towards integrating ICT-supported learning into their classrooms. As a perusal of Table 3 indicates, 50\% of the 40 teachers who responded to the survey indicated that they were using a variety of ICT tools to facilitate the use of ICT by their students; whereas, only $10 \%$ indicated that they were using ICT tools to reflect and share their teaching practices with colleagues. It is interesting to note how the fourth level in this self-assessment is designed to encourage teachers to reflect on the degree to which they are sharing their knowledge with others in the community of practice. By doing so, the BCT Lead Team hoped to encourage teachers to take another "deliciously uncertain" step towards the building of an active professional community of practice, that is, a step just hard enough to make it interesting but not so hard as to discourage people. In fact, it is interesting to note that during the past six months there has been a significant increase in the use of the BCT Sakai Portal by the teachers to communicate and collaborate with each other. 
Table 3:

Self-Assessment of Personal Progress on the BCT Journey

\begin{tabular}{l|l|l} 
LEVELS & $\begin{array}{l}\text { DESCRIPTIONS } \\
\text { I use ICT tools for personal purposes, e.g., email, Word, Internet } \\
\text { search, Facebook, etcetera }\end{array}$ & $0 \%$ \\
\hline II & $\begin{array}{l}\text { I use ICT tools to support my teaching, e.g., LCD projector, } \\
\text { PowerPoint, Internet, Smartboard, etcetera }\end{array}$ & $40 \%$ \\
\hline $\begin{array}{l}\text { III } \\
\text { In }\end{array}$ & $\begin{array}{l}\text { order to facilitate ICT use by my students, I: } \\
\text { integrate the use of ICT into the QEP curriculum } \\
\text { facilitate peer support } \\
\text { provide opportunities to develop group projects includ- } \\
\text { ing online } \\
\text { encourage and develop collaborative group strategies }\end{array}$ & $50 \%$ \\
\hline $\begin{array}{l}\text { I use ICT tools to reflect and share my teaching practices with } \\
\text { colleagues: } \\
-\quad \begin{array}{l}\text { by contributing to an online community of practice } \\
\text { accessing online support } \\
\text { posing relevant questions to colleagues in the network }\end{array}\end{array}$ & $10 \%$ \\
\hline
\end{tabular}

\section{Do BCT teachers believe their students benefit from ICT-supported learning?}

One of the key findings in the CEFRIO Report was the importance of teachers believing that the use of ICT tools in their classrooms would actually help their students learn more effectively. It was believed that if teachers held this belief they would be more willing to acquire the skills they needed to use ICT-supported learning in their classrooms. From the first year of the project, flipchart paper and sticky notes were used to encourage teacher input on this question. An early example of this type of teacher inquiry involved the use of this question: What's In It for Our Students? The teachers responded to this question by posting separate sticky notes 
on a flipchart and the results were organized into categories and shared online for additional comments. Table 4 presents the results obtained from posing the above question. The number of responses posted in each of the six categories is noted in brackets along with examples of the items in each category that were posted by the teachers.

\section{Table 4:}

\section{Results of the What's in It for Our Students Inquiry}

\begin{tabular}{|c|c|c|}
\hline $\begin{array}{l}\text { Effects on } \\
\text { Student Learning }\end{array}$ & $\begin{array}{ll}\text { - } & \text { children are taking ownership of their own learning } \\
\text { - } & \text { excitement in the classroom } \\
\text { engaged by different learning opportunities }\end{array}$ & 16 \\
\hline $\begin{array}{l}\text { Broadening } \\
\text { Horizons and } \\
\text { Student } \\
\text { Networking }\end{array}$ & $\begin{array}{l}\text { "meet" other schools and students - authentic } \\
\text { audience } \\
\text { opportunity to interact with other students in } \\
\text { different regions } \\
\text { - } \quad \text { taking a more global and broader perspective }\end{array}$ & 16 \\
\hline $\begin{array}{l}\text { Opportunities to } \\
\text { Learn IT Skills }\end{array}$ & $\begin{array}{l}\text { - } \quad \text { students learn about and with technology } \\
\text { - } \quad \text { learn to use different forms of technology properly } \\
\text { - } \quad \text { access to more technology and learn related skills }\end{array}$ & 12 \\
\hline $\begin{array}{l}\text { Curriculum and } \\
\text { QEP }\end{array}$ & $\begin{array}{l}\text { - } \quad \text { cross-curricular teaching } \\
\text { - } \quad \text { new ideas and lessons for my students } \\
\text { - } \quad \text { work on language skills, art, social studies }\end{array}$ & 10 \\
\hline $\begin{array}{l}\text { Developing } \\
\text { Collaboration }\end{array}$ & $\begin{array}{l}\text { - } \quad \text { learn how to work together } \\
\text { - } \quad \text { collaboration-sharing of ideas } \\
\text { - } \quad \text { involvement in collaborative projects }\end{array}$ & 9 \\
\hline
\end{tabular}

Subsequently, a set of inquiry-based survey items related to the benefits of student learning were created. The following set of questions related to student learning was included in a survey conducted during the second year of the project. As an analysis of the results in Table 5 shows, on a five-point scale, teachers clearly indicated that their students enjoyed sharing their work with authentic audiences and they enjoyed learning about and with ICT tools. However, when the teachers were asked whether the students in their classes were taking increased ownership for their own learning and whether they were learning how to collaborate more effectively, the teachers who were in their second year agreed with these items to some 
extent but those who were in their first year were less willing to do so. Finally, when asked if their students understood the importance of digital etiquette and if they were trying to use ICT tools more appropriately, teachers in both years of the project indicated that they only agreed to some extent. The above results show there was still a considerable amount of student learning that needed to be encouraged.

\section{Table 5:}

\section{Results of the Inquiry-Based Survey Questions on Student Learning}

DESCRIPTIONS

YEAR 1 YEAR 2

The students enjoy sharing their work with "authentic audiences" such as other students, parents and friends

The students enjoy learning about and with information technology

The students are taking increased ownership for their own learning

The students are learning how to collaborate more effectively with others

The students understand the importance of digital etiquette and are trying to use ICT more appropriately

\section{How are BCT teachers encouraged to share their craft knowledge?}

A number of different strategies have been used to encourage BCT teachers to share their concerns, ideas and feelings about teaching and learning. In our initial BCT F2F meetings, some teachers readily shared their ideas while others were more reticent about doing so. Over the past several years, during BCT F2F sessions, information on the value of teachers sharing their craft knowledge was discussed. As the research on teacher learning has shown, teachers are often quite reticent about sharing the successes and challenges that they face when teaching. Based on several strategies from the professional learning literature (Bubb \& Earley, 2009; Easton, 2008; Killion \& Roy, 2009), the Cycle Leaders facilitated group discussions to help teachers express their concerns, ideas and feelings regarding the sharing of their craft knowledge. At the same time, they called for suggestions on how to encourage more open discussion of teaching practices in $\mathrm{F} 2 \mathrm{~F}$ and online situations. A wide range of suggestions were generated during these discussions; however, the following three ideas 
garnered considerable support: (a) the importance of establishing a suitable place and time during school hours for teachers to meet, (b) the recognition that those involved must be willing to share their craft knowledge, and (c) the value of having teacher-leaders within the group to facilitate the sharing, discussing and constructing of knowledge. As the above suggestions show, the use of teacher inquiry questions resulted in some important insights on how to facilitate the sharing of teacher knowledge.

Over the past few years, based on feedback from the teachers, input from the BCT Cycle Leaders and the adaptation of ideas from the research literature on professional learning (Bambino, 2002; Costa \& Kallick, 1993; Easton, 2008; Glazer \& Hannafin, 2006; Killion \& Roy, 2009; Swaffield, 2008), a collaborative group learning protocol was developed based on the acronym: SHARE. Figure 2 presents the key steps in the SHARE protocol. These basic steps were discussed with the teachers and during a F2F session its use was modeled by the Cycle Leaders and then by small groups from each cycle. Since that session, the BCT Cycle Leaders have encouraged teachers to use this collaborative group learning process as it provides structure and a degree of safety that has been shown to encourage increased teacher sharing.

\section{Select a relevant teaching-learning activity:}

The presenter selects a relevant teaching-learning activity to share with the collaborative learning group.

Highlight the key aspects of the learning experience:

The presenter briefly explains the purpose, process and results that were obtained, highlighting the aspects that were important to its success.

\section{Ask clarifying questions:}

Group members ask questions to more fully understand the teachinglearning activity so they can respond to it.

\section{Reflect on the teaching-learning activity:}

Group members reflect, review, and react to the presenter's ideas on the teaching-learning activity by commenting on its strengths, posing questions about it, and making suggestions.

\section{Evaluate the lessons learned:}

The presenter summarizes the lessons gained from the feedback of group members and comments on the effectiveness of the process that was used.

Fig. 2: SHARE - A collaborative group learning protocol 


\section{How do BCT teachers develop collaborative student projects?}

As noted above, teacher input and ownership has been a central theme in the BCT Project. During the second year of the project, in a November F2F meeting teachers were asked to brainstorm the question: What does a good collaborative project look like? Within minutes of asking the question, a variety of ideas were shared and a principal who was present kindly agreed to record and organize the results. As the results of this teacher-based inquiry in Table 6 show, by the second year of the project, the BCT teachers had developed a fairly good understanding of the key factors that influence the development of a sound collaborative student learning project.

Table 6:

Results for the What Does a Good Collaborative Project Look Like?

\begin{tabular}{|c|c|}
\hline Purpose & $\begin{array}{l}\text { - Set a goal and purpose } \\
\text { It is not parallel play-there needs to be built-in knowledge } \\
\text { building } \\
\text { - Knowledge building-may happen at school level but the } \\
\text { hope/goal is to explore outer world (beyond the school/ } \\
\text { classroom walls) }\end{array}$ \\
\hline Teamwork & $\begin{array}{l}\text { - Team: sharing, discussing, reflecting, assessing, being } \\
\text { creative, practical.... } \\
\text { - } \quad \text { Set a goal and purpose } \\
\text { - } \quad \text { Discussion groups - set a time } \\
\text { - } \quad \text { Set time frames: } 3-4 \text { days / a week....a month, etcetera } \\
\text { - } \quad \text { Use Skype / Live Classroom to communicate with collaborators } \\
\text { - } \quad \text { Have a recorder for the discussion and put it on a wiki or blog }\end{array}$ \\
\hline $\begin{array}{l}\text { Monitoring } \\
\text { Progress }\end{array}$ & 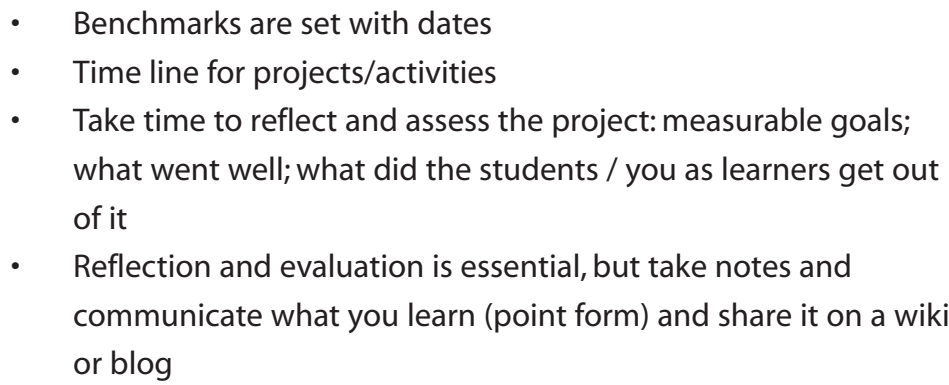 \\
\hline
\end{tabular}


\begin{tabular}{l|ll} 
Collaborative & $\cdot$ & Be willing to take risks and learn new ideas \\
Learning & $\cdot$ & Model what we want students to do \\
Process & $\cdot \quad \begin{array}{l}\text { Don't be afraid that we are learning and taking risks } \\
\text { - }\end{array}$ & Can learn from those outside their school
\end{tabular}

In subsequent F2F and online meetings, the question of how to develop a good collaborative project continued to be addressed. Based on those discussions, during the third year of the project, one of the teachers in cooperation with a BCT Lead Team member developed a process to facilitate the development of collaborative student projects based on the acronym COLLABORATE with the key steps in the process outlined in bullet-point form. The process was shared with the BCT teachers and then placed in the Resources file in the BCT Sakai Portal (http://sakai.learnque bec.ca) and the BCT website (http://bctcollaboration.wikispaces.com). The above acronym-based process was used to facilitate the development of collaborative projects during the third year of the project; however, during the first F2F meeting of the fourth year of the project, a shorter, more teacher-friendly version was developed in PowerPoint form by two of the Cycle Leaders on the BCT Lead Team (see http://bct collaboration.wikispaces.com/Designing+a+Collaborative+Project). Figure 3 presents the summary of the key steps in the latest version of the COLLABORATE process.

Consider: Consider potential topics that are interesting and relevant

Outline: Outline the purpose of the project and its key features

Listen: Listen to each other to develop and shape the project

List: List the key aspects of the project and its final product

Assess: Assess whether the project is doable and realistic

Build: Build a plan to guide work on the project

Organize: Organize into teams to get things done

Review: Review the progress that is being made

Assemble: Assemble the parts of the project

Try: Try a trial presentation

Evaluate: Evaluate the product and share

Fig. 3: COLLABORATE - A process for developing collaborative student projects 
As the above information shows, the input of teachers based on their experiences in the classroom has definitely shaped the professional learning resources used in the project. In fact, the above COLLABORATE process is currently guiding the development of student collaborative projects in each of the three cycle teams.

\section{How do administrators support the BCT Project?}

Over the past four years, an absolutely essential aspect of the BCT Project has been the ongoing support provided by the principals and vice-principals involved in it. Each year, these administrators are encouraged to attend at least two of the BCT F2F meetings in order to keep informed about the project and provide feedback on its progress. In addition, they receive a report of all of the sticky notes submitted by the teachers in the Appreciative Inquiry process that is conducted after each F2F session, which updates them on how the teachers view the benefits of the project, the suggestions the teachers made to make it even better, and any questions or suggestions the BCT Lead Team should consider (Cooperrider \& Whitney, 2005).

At times, working groups of administrators have met to discuss a variety of technical, financial and support questions. An example of this type of activity was the work of a small group who developed a set of potential guidelines for administrators to consider when they are trying to support teacher involvement in a community of practice such as the BCT Project. A draft of these suggested guidelines was developed and in a subsequent F2F meeting, the administrators present reviewed the draft guidelines and edited them. The results of that process are presented in Figure 4: 
Educational leaders at the school level play an important role in supporting the involvement of teachers in the BCT project. They do so in a variety of ways, some of which are described below:

1. Provide common release time: Designing the teaching schedule so that teachers can get together to share ideas and develop collaborative projects is one of the most important ways that administrators can support the BCT initiative.

2. Encourage, empower and support teachers: As teachers are learning the pedagogical and technological skills that they require, it is important for administrators to encourage them, especially during the inevitable ups and downs of the learning process. Openly encouraging risk-taking and indicating that it is alright to fail are other ways to support the ongoing professional learning process.

3. Provide the technology and time for hands-on learning of ICT tools: Teachers need to have appropriate technical resources and time to actually practice using the ICT tools that they will use in their classrooms. Again, trying to provide professional learning time and an appropriate location for teachers to do so is an important administrative support strategy.

4. Assure technical support is available when required: Facilitating the access to technical support has been shown to be of great importance in motivating teachers to integrate ICT into their classroom practices. Building ongoing relationships with technical staff and providing up-to-date computers and accessories are two ways to reach this goal.

5. Showcase the products of ICT-supported learning: Experienced administrators report that face-to-face and online opportunities that allow students to demonstrate the planning, implementation, and evaluation of ICT supported projects is an effective way to increase public understanding and support.

6. Reinforce that ICT use is not an "add-on": Experienced BCT teachers and educational leaders continually emphasize that the use of ICT tools should not be viewed as an "add on," rather it should be seen as an integral part of QEPbased teaching and learning.

Fig. 4: Suggestions on how to support teachers in the BCT project 


\section{Six Lessons Learned}

Teacher inquiry has allowed us to identify and collaboratively address key questions related to the development of a viable community of practice. As we look back, there are a number of lessons learned that have been generated. First, teacher involvement and feedback allowed us to address a wide variety of needs as they emerged. Second, the Cycle Leaders played a central role in shaping the project due to their classroom experiences and the collegial trust they developed. Third, the ongoing support of school and school board administrators, RÉCIT animators, as well as LEARN Quebec and CEFRIO colleagues was of fundamental importance. Fourth, taking a long-term perspective on educational change was important as it takes time for teachers to acquire the competence and confidence to change their practice. Fifth, the mixture of face-to-face and online communication and collaboration allowed for just-in-time support, collaborative planning and action, the sharing of teaching practices, and the generation of new knowledge over the course of the project. Sixth, a final lesson learned was the importance of building collegial trust and having fun along the way.

\section{References}

Aulls, M. W., \& Shore, B. M. (2008). Inquiry in education (vol. l): The conceptual foundations for research as a curricular imperative. New York: Erlbaum.

Bambino, D. (2002). Critical friends, Educational Leadership, 59(6), 25-27.

Bereiter, C. (2005). Design research: The way forward. Education Canada, 46(1), 16-19.

Breuleux, A., Heo, G. M., Wall, T., Morgan, L., \& Flores, L. (2009). Building community through telecollaboration (BCT) project in Quebec. Proceedings of the Society for Information Technology \& Teacher Education International Conference (SITE) 2009, Charleston, SC, USA.

Brown, A. L. (1992). Design experiments: Theoretical and methodological challenges in creating complex interventions in classroom settings. Journal of the Learning Sciences, 2(2), 141-178.
Bubb, S., \& Earley, P. (2009). Leading staff development for school improvement. School Leadership \& Management, 29(1), 23-37.

Collins, A., Joseph, D., \& Bielaczyc, K. (2004). Design research: Theoretical and methodological issues. Journal of the Learning Sciences, 13(1), 15-42.

Cooperrider, D. L., \& Whitney, D. K. (2005). Appreciative inquiry: A positive revolution in change. San Francisco: Berrett-Koehler Publishers.

Costa, A. L., \& Kallick, B. (1993). Through the lens of a critical friend. Educational Leadership, 51(2), 49-51.

Darling-Hammond, L., Wei, R. C., Andree, A., Richardson, N., \& Orphanos, S. (2009). Professional learning in the learning profession: A status report on teacher development in the United States and abroad. Dallas, TX: National Staff Development Council. 
Easton, L. (2008). From professional development to professional learning. Phi Delta Kappan, 89(10), 755-761.

Garrison, D. R. (2007). Online community of inquiry review: Social, cognitive, and teaching presence issues. Journal of Asynchronous Learning Networks, 11(1), 61-72.

Glazer, E., \& Hannafin, M. J. (2006). The collaborative apprenticeship model: Situated professional development within school settings. Teaching and Teacher Education, 22(2), 179-193.

Heo, G. M., Anderson, D., Goyetche, M-H., Taker, D., \& Breuleux, A. (2011). Distributed leadership facilitating collaboration in a teacher community of practice. Proceedings of the Society for Information Technology \& Teacher Education International Conference (SITE) 2011, Nashville, Tennessee, USA.

Killion, J., \& Roy, P. (2009). Becoming a learning school. Oxford, OH: National Staff Development Council.

Laferrière, T., Breuleux., A., Allaire, S., Hamel, C., Turcotte, S., \& Beaudoin, J. (2006). The remote networked schools: Phase II report summary. Quebec: CEFRIO. Retrieved February 26, 2011 from http://www.cefrio. qc.ca/fileadmin/documents/Projets/Synth eseEERphase-2anglaisfinal.pdf

Moore, J., \& Barab, S. (2002). The inquiry learning forum: A community of practice approach to online professional development. TechTrends, 46(3), 44-51.
Palincsar, A. S., Magnusson, S. J., Marano, N., Ford, D., \& Brown, N. (1998). Designing a community of practice: Principles and practices of the GIsML community. Teaching and Teacher Education, 14(1), 5-19.

Schlager, M. S., \& Fusco, J. (2003). Teacher professional development, technology, and communities of practice: Are we putting the cart before the horse? The Information Society, 19, 203-220.

Schoenfeld, A. H. (2006). Design experiments. In J. L. Green, G. Camilli, \& P. B. Elmore (Eds.). Handbook of complementary methods in education research (pp. 193-205). Mahwah, $\mathrm{NJ}$ : Lawrence Erlbaum.

Swaffield, S. (2008). Critical friendship, dialogue and learning, in the context of leadership for learning. School Leadership \& Management, 28(4), 323-336

Wall, A. E., Breuleux, A., \& Tanguay, V. (2006). ITsupported learning and networking in the Anglophone educational community of Québec. Quebec: CEFRIO.

Wenger, E. (1998). Communities of practice: Learning, meaning, and identity. NY: Cambridge University Press.

Wenger, E., McDermott, R., \& Snyder, W. M. (2002). Cultivating communities of practice: A guide to managing knowledge. Boston: Harvard Business School Press.

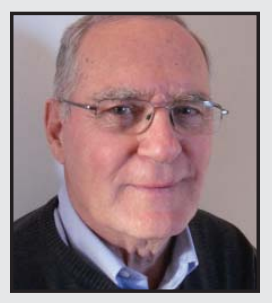

A. E. Ted Wall is a retired Professor from McGill University where he served as the Dean of the Faculty of Education. In 2006, he co-authored the CEFRIO Research Report with Dr. Alain Breuleux and Vincent Tanguay entitled: IT-Supported Learning and Networking in the Anglophone Educational Community of Québec. Over the past four years, he has been a member of the Lead Team for the Building Community through Telecollaboration Project that is sponsored by MELS, CEFRIO and LEARN Quebec. 


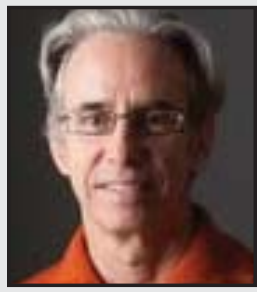

Alain Breuleux is a cognitive psychologist collaborating with school teachers and administrators to design and investigate sustainable technology-enabled networks for learning and advanced pedagogical practices. In recent years, he has led collaborative research to understand how children and educators in small remote schools in the Province of Quebec can best use Internet and multimedia tools to construct and share knowledge (L'École Éloignée en Réseau and Building Community through Telecollaboration). The research in these design experiments looks at attitudes, motivation, interaction, and learning.

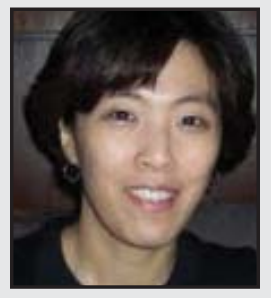

Gyeong Mi Heo is an Education Consultant at the Centre francophone d'informatisation des organisations. She has worked for the BCT project for four years as a researcher and facilitator. She received her Ph.D. and M.A. in Educational Psychology from McGill University. Her major was Applied Cognitive Science and her minor was Computer Application in Education. Her research focuses on how technology can support teaching and learning in formal, non-formal and informal learning situations in terms of communities of practice and collaborative learning.

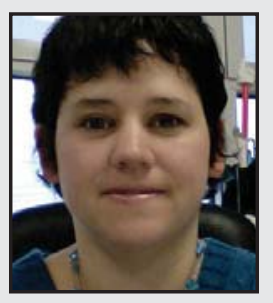

Karen Rye is a Cycle 3 teacher at St. Johns Elementary School in the Riverside School Board. She has been a part of the BCT project for four years, acting as Cycle 3 Lead Teacher for the past two. She has a keen interest in learning how to integrate technology into classroom instruction as a way of motivating students and improving overall results. She likes to work collaboratively with other teachers as a way of improving herself as a teacher and increasing the opportunities for her students to learn. 


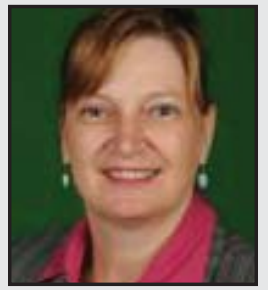

Marie-Helen Goyetche is the Principal at Arundel Elementary School in the Sir Wilfrid Laurier School Board. She has been part of the BCT project for three years, and has been the Cycle 2 Lead Teacher for the past two. She has an overwhelming passion for Web 2.0 ICT tools. She is always looking for ways to connect and learn with her students, teachers and fellow administrators.

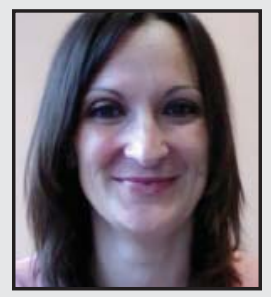

Véronique Lemay is a Cycle 1 teacher at St. Johns Elementary School in the Riverside School Board. This is her first year as a Cycle Leader for the BCT project. She enjoys collaborating on projects across cycles and incorporating technology in her classroom. She is always looking for creative ways to engage her students. This project has enabled her to grow a great deal both as a leader and a learner.

\section{LINK TO:}

http://bctcollaboration.wikispaces.com/ 